\title{
Investigation of the positivity profile for the skin prick test in children infected with parasites in the metropolitan region of Pernambuco, Northeast of Brazil
}

\author{
Victor Torres Teodósio ${ }^{*}$, Wheverton Correia Do Nascimento ${ }^{1}, C^{\prime}$ ássia Oliveira Nóbrega', Tiago Elias Melo',

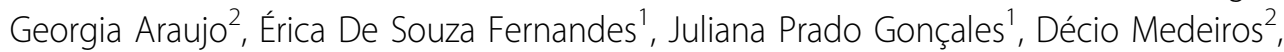 \\ Constança Simões Barbosa', Valdênia Oliveira De Souza'
}

From 3rd WAO International Scientific Conference (WISC) 2014

Rio de Janeiro, Brazil. 6-9 December 2014

\section{Background}

Parasitic infections induce Th2 cell immune profile and modulate the symptoms of asthma and rhinitis. The objective is to analyze the modulation of parasitic infection in the skin prick test profile in children with asthma from two localities in the metropolitan region of Recife - Pernambuco.

\section{Methods}

Children between 2 and 14 year old were submitted to a parasitological survey using the Hoffman, Pons e Janer (3 blades) method and the Kato-Katz (2 blades) method. The ISAAC questionnaire was applied to collect informations related to asthma. The Skin Prick Test was applied using extracts of Dermatophagoides pteronyssinus (DP), Blomia tropicalis (BT), Blatella germânica (BG), Periplaneta americana (PA), fungus and cat epithelium (EPC).

\section{Results}

Sixty-two children were registered, 35 (65,17\%) classified as having asthma by ISAAC. Between asthmatics 11 $(31,42 \%)$ were infected with parasites and 24 noninfected (68,58\%). Among non-asthmatic children $(\mathrm{n}=27$, 43,54\%), 25 were infected (92,6\%) and 2 non-infected $(7,4 \%)$. The parasites identified in asthmatic children were Enterobius vermicularis ( $\mathrm{n}=2,18,18 \%)$, Ascaris lumbricoides, Trichuris trichiura and Ancylostoma sp
( $\mathrm{n}=1,9,09 \%)$, Giardia lamblia $(\mathrm{n}=5,45,45 \%)$, T. trichiura and Ancylostoma sp $(\mathrm{n}=1,9,09 \%)$, T. trichiura and A. lumbricoides $(\mathrm{n}=1,9,09 \%), T$. trichiura $(\mathrm{n}=1$, 9,09\%); within the non-asthmatic were A. lumbricoides $(\mathrm{n}=3,12 \%)$, G. lamblia $(\mathrm{n}=10,40 \%)$, T. trichiura $(\mathrm{n}=6$, 24\%), Schistosoma mansoni ( $\mathrm{n}=1,4 \%)$, Ancylostoma sp $(\mathrm{n}=2,8 \%)$, S. mansoni, T. trichiura e Ancylostoma sp ( $\mathrm{n}=1,4 \%)$, T. trichuris, A. lumbricoides and Ancylostoma $s p(\mathrm{n}=2,8 \%)$. The prick test was positive in 18 children $(29,03 \%)$, with 7 infected $(11,29 \%)$ and 11 not infected $(17,74 \%)$. The positivity profile of the prick test were 2 children only for DP (11,11\%), 1 for BT (5,55\%), 11 for DP and BT (61,11\%), 1 for DP, BT and fungus (5,55\%), 1 for DP, BT, BG, PA and EPC (5,55\%), and 1 for BT, $\mathrm{BG}$ and PA $(5,55 \%)$.

\section{Conclusion}

The parasitic infection was more frequent in non-asthmatic children. It was not possible to verify alterations in the positivity of the prick test among asthmatic children and the association with parasitic infections. The most frequent allergens in the positivity of the prick test was Dermatophagoides pteronyssinus and Blomia tropicalis.

\section{Authors' details}

'Research Center Aggeu Magalhães - Fundação Oswaldo Cruz, Brazil. ${ }^{2}$ Federal University of Pernambuco, Brazil. 
doi:10.1186/1939-4551-8-S1-A241

Cite this article as: Teodósio et al:: Investigation of the positivity profile for the skin prick test in children infected with parasites in the

metropolitan region of Pernambuco, Northeast of Brazil. World Allergy

Organization Journal 2015 8(Suppl 1):A241.

Submit your next manuscript to BioMed Central and take full advantage of:

- Convenient online submission

- Thorough peer review

- No space constraints or color figure charges

- Immediate publication on acceptance

- Inclusion in PubMed, CAS, Scopus and Google Scholar

- Research which is freely available for redistribution

Submit your manuscript at www.biomedcentral.com/submit
() Biomed Central 